\title{
The Current State of Validation of Administrative Healthcare Databases in Italy: A Systematic Review
}

\author{
Iosief Abraha ${ }^{1, *}$, Massimiliano Orso ${ }^{1}$, Piero Grilli ${ }^{4}$, Francesco Cozzolino ${ }^{1}$, Paolo Eusebi ${ }^{1}$, \\ Paola Casucci $^{2}$, Mauro Marchesi ${ }^{3}$, Maria Laura Luchetta ${ }^{4}$, Luisa Fruttini ${ }^{5}$, \\ Raoul Ciappelloni ${ }^{5}$, Rita De Florio ${ }^{4}$, Gianni Giovannini ${ }^{1}$ and Alessandro Montedori ${ }^{1}$
}

\author{
${ }^{1}$ Regional Health Authority of Umbria, Health Planning Service, Perugia, Italy \\ ${ }^{2}$ Regional Health Authority of Umbria, Health ICT Service, Perugia, Italy \\ ${ }^{3}$ Azienda Ospedaliero-Universitaria di Perugia, Servizio Immunoematologia e Trasfusionale, Perugia, Italy \\ ${ }^{4}$ Azienda Sanitaria Locale USL 2, Medicina Generale, Terni, Italy \\ ${ }^{5}$ Istituto Zooprofilattico Sperimentale dell'Umbria e delle Marche, Unità Operativa Editoria Biblioteca, Perugia, \\ Italy
}

\begin{abstract}
Background: Administrative healthcare databases are widely present in Italy. Our aim was to describe the current state of healthcare databases validity in terms of discharge diagnoses (according to the International Classification of Diseases, ICD-9 code) and their output in terms of research.

Methods: A systematic search of electronic databases including Medline and Embase (1995-2013) and of local sources was performed. Inclusion criteria were: healthcare databases in any Italian territory routinely and passively collecting data; medical investigations or procedures at patient level data; the use of a validation process. The quality of studies was evaluated using the STARD criteria. Citations of the included studies were explored using Scopus and Google Scholar.

Results: The search strategy allowed the identification of 16 studies of which 3 were in Italian. Thirteen studies used regional administrative databases from Lombardia, Piemonte, Lazio, Friuli-Venezia Giulia and Veneto. The ICD-9 codes of the following diseases were successfully validated: amyotrophic lateral sclerosis (3 studies in four different regional administrative databases), stroke (3 studies), gastrointestinal bleeding (1 study), thrombocytopenia ( 1 study), epilepsy (1 study), infection (1 study), chronic obstructive pulmonary disease (1 study), Guillain-Barre syndrome (1 study), and cancer diseases (4 studies). The quality of reporting was variable among the studies. Only 6 administrative databases produced further research related to the validated ICD-9 codes.
\end{abstract}

Conclusion: Administrative healthcare databases in Italy need an extensive process of validation for multiple diagnostic codes to perform high quality epidemiological and health services research.

Keywords: Healthcare databases, Sensitivity, Specificity, Predictive values, Health administrative data, Diagnostic accuracy, Misclassification bias, Diagnostic accuracy, Health services research, Epidemiology.

\section{BACKGROUND}

Administrative healthcare databases are becoming a widely used tool for epidemiological studies, health services research, comparative effectiveness investigations of drugs and devices, post-marketing surveillance, drug prescription patterns, and outcome research [1, 2]. Most of the databases contain electronically recorded diagnostic information that are expressed as codes of the International Classification of Diseases ICD-9 or ICD-10 [3]. To constitute a reliable resource for research, the diagnostic discharge data should be of high quality and closely correspond to the electronic information in the administrative database [4, 5]. There are many administrative

*Address correspondence to this author at the Regional Health Authority of Umbria, Health Planning Service, Perugia, Italy; Tel: +390755045251;

Fax: +390755045569; E-mail: iosief_a@yahoo.it databases worldwide in which this process of validation has been successfully performed for many diagnostic codes, making them value tools $[1,6-9]$.

In Italy, the provision and delivery of almost all health care services are performed by 21 Regional Health Authorities, each of whom maintains large healthcare databases with information on drug prescriptions, medical records from private and public hospitals, vital statistics, and demographic data for all residents identified by a unique national identification code [10]. These databases are often used for drug utilization studies [11], epidemiology [8, 12], health services research [13], and health economics [14], but nothing is known about the current state of the healthcare databases that have validated ICD-9 codes.

Our goal was to systematically identify the number of administrative healthcare databases in Italy that had 
validated diagnostic codes; to describe the type and number of diagnoses validated; and to describe epidemiological, health services research and other forms of research performed with these validated ICD-9 codes.

\section{METHODS}

A systematic search of electronic records, from January 1, 1995 to December 31, 2013, in the Medline (via Ovid) and Embase (via Embase.com) databases, was performed. We used a search strategy developed by Benchimol et al. [15], designed to capture studies that use healthcare administrative databases (see Appendix). Italian websites of healthcare services at the national, regional and local levels, as well as reference lists of retrieved articles and hand searches of pertinent Italian journals (Epidemiologia $e$ Prevenzione and Annali di Igiene) were examined for relevant publications.

To be included, studies needed to satisfy the following criteria: 1) to have routinely used healthcare databases in any Italian territory, routinely and passively collecting data without an a priori research question; 2) to have contained a patient-related health outcome, medical investigation or procedure; and 3) to have employed a validation process. Studies using databases that were not truly administrative (e.g. cancer registries, epidemiology surveillance systems, etc.) were excluded. No language restriction was used.

Studies were included if they used databases containing significant clinical information (e.g., pathology/histology results, laboratory or microbiological data, chart notes, etc.), vital statistics (i.e., births and deaths) and disease registries (unless these data were used as the reference standard for validation of the administrative data). Studies using databases that contained data from quality improvement programs, or that validated the performance of comorbidity measures, were excluded unless they also validated the identification of disease components of the measure.

The quality of the included studies was evaluated using a checklist developed by Benchimol et al. [15], based on the criteria published by the Standards for Reporting of Diagnostic accuracy (STARD) initiative for the accurate reporting of investigations of diagnostic studies [16].

To evaluate the performance of the validated administrative healthcare databases in terms of epidemiological or health services research and other forms of subsequent research, we identified the citations from the medical literature of the published studies, following the first publication describing the validation of the administrative database. We used the Scopus database (www.scopus.com) and Google Scholar to identify the related citations (March 1, 2014).

Two authors independently screened titles and abstracts for inclusion (MLL, RDF). Disagreement was resolved by consensus. Two authors independently reviewed all the included studies and assessed the quality of reporting (FC, MO). Disagreement was resolved by consensus.

The distribution of various characteristics of the examined studies were reported using descriptive statistics.

\section{RESULTS}

The initial electronic search in Medline and Embase returned 12,939 citations. After screening titles and abstracts, we selected 54 reports for more detailed evaluation. In addition, 34 articles were identified from an Internet search, a reference check and a hand search of Italian journals for which full-text versions were obtained for further evaluation (Figure 1). Overall 88 full-text articles were evaluated, which identified 16 studies that satisfied the inclusion criteria.

\section{Description of Excluded Studies}

Seventy-two studies were excluded from the review following full-text eligibility assessment. Most of the studies were not validation studies. However, some studies that did carry out validation, deserve some description: one study that validated ICD-9 codes for rheumatoid arthritis was excluded because it was published only as an abstract [17]; one study, despite attempting to assess misclassification of chronic obstructive pulmonary disease cases (COPD) from administrative databases, it did not use an adequate reference standard to validate COPD ICD-9-CM codes [18]; one study that validated ICD-9 codes for myocardial infarction in a network of three European countries, did not use an administrative database for the Italian data $[19,20]$, and two studies that considered infectious diseases [21, 22] did not use an adequate reference standard, were excluded from the analysis. The complete list of excluded studies, with reasons for the exclusion, is presented in the Supplemental Material. 


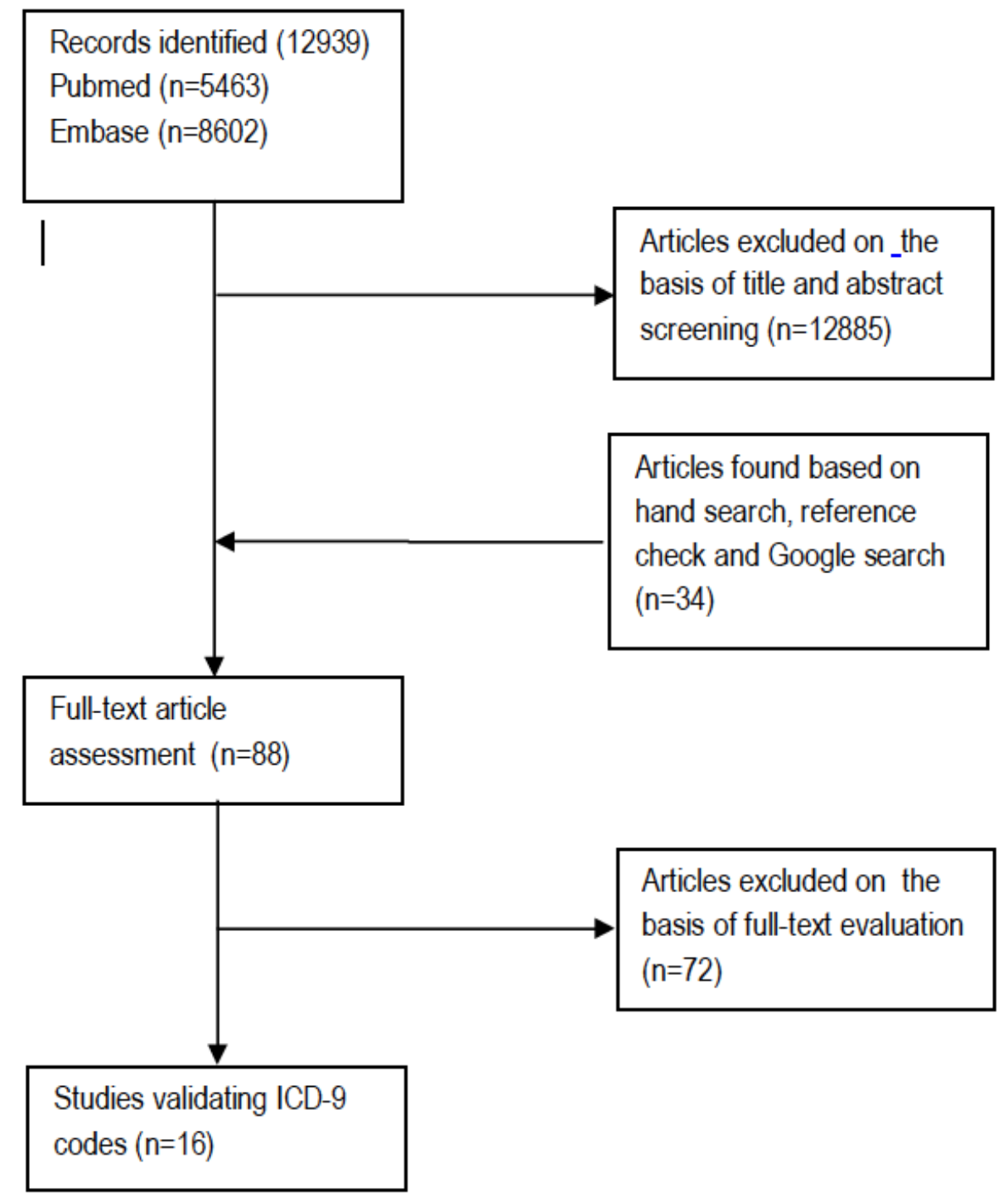

Figure 1: Study screening process.

\section{Description of Included Studies}

The 16 studies that were included in this systematic review were all published as full-text articles between 1999 to 2013. Three studies were published in Italian [23-25]. The coverage of the data was at regional level (9 studies [22, 24, 26-32]), provincial level (1 study [33]), district level (2 studies [23, 34]), and hospital level (4 studies [25, 35-37]). Five studies used ICD-9$\mathrm{CM}$ codes for validation $[25,30,31,34,35]$ and the remaining studies used the older version of ICD-9. Nine studies had as a primary aim to assess the validity of hospital discharge diagnoses. The basic characteristics of the studies are presented in Table 1.

\section{Validated Disease Codes}

The following codes were considered for validation: stroke related codes ( 3 studies: 1 performed at the regional level (Veneto) [32] and 2 at the hospital level (Novara [36] and Lugo di Romagna [37]); amyotrophic lateral sclerosis related codes ( 3 studies at the regional level in Lombardia [33], Piemonte and Valle d'Aosta [29], and Friuli-Venezia Giulia [30]); gastrointestinal bleeding related codes (1 study performed at the regional level Friuli-Venezia Giulia [28]); thrombocytopenia related codes (1 study performed at the hospital level [35]); epilepsy related codes (1 study performed at the district of Lecco [34]); COPD related codes (1 study performed at the hospital level [25]). Two studies that evaluated lymphoid malignancies in the district of Reggio Emilia [23] and infections in all rehabilitation units in Lombardia [22] did not list the number of the ICD-9 codes. The remaining studies evaluated codes of different malignancies that are described in Table 1. 
Table 1: Characteristics of Included Studies

\begin{tabular}{|c|c|c|c|c|c|c|}
\hline Study ID & Study aim & Source & $\begin{array}{l}\text { Enrollment } \\
\text { period }\end{array}$ & $\begin{array}{l}\text { Reference } \\
\text { standard }\end{array}$ & $\begin{array}{l}\text { Type of disease: } \\
\text { ICD-9 code } \\
\text { validated }\end{array}$ & $\begin{array}{l}\text { Measure of } \\
\text { accuracy } \\
\text { used }\end{array}$ \\
\hline Baldi 2008 & $\begin{array}{l}\text { To develop algorithm to identify } \\
\text { incidence cancer cases }\end{array}$ & Piemonte region & $2000-2001$ & $\begin{array}{l}\text { Regional } \\
\text { Cancer } \\
\text { Registry }\end{array}$ & $\begin{array}{c}\text { Breast cancer: } \\
\text { 174.0-174.9; } \\
\text { 233.0; Colon } \\
\text { cancer: 153.0- } \\
\text { 153.9, 154.0- } \\
\text { 154.1, 154.8; lung } \\
\text { cancer: 162.0- } \\
\text { 162.9. }\end{array}$ & SE; PPV \\
\hline Beghi 2001 & $\begin{array}{l}\text { To assess the validity of the hospital } \\
\text { discharge for ALS epidemiology }\end{array}$ & $\begin{array}{l}6 \text { provinces } \\
\text { (Lombardia } \\
\text { region) }\end{array}$ & 1994-1995 & $\begin{array}{c}\text { Medical } \\
\text { chart review }\end{array}$ & $\begin{array}{l}\text { Motor neuron- } \\
\text { disease: } 335.2\end{array}$ & SE, SP, PPV \\
\hline $\begin{array}{l}\text { Bogliun } \\
2002\end{array}$ & $\begin{array}{c}\text { To assess the validity of hospital } \\
\text { discharge diagnoses } \\
\text { as a tracer of the Guillain-Barrè } \\
\text { syndrome }\end{array}$ & $\begin{array}{l}\text { Lombardia } \\
\text { region }\end{array}$ & 1996 & $\begin{array}{l}\text { Regional } \\
\text { Guillain- } \\
\text { Barrè } \\
\text { syndrome } \\
\text { registry / } \\
\text { medical } \\
\text { chart review }\end{array}$ & $\begin{array}{l}\text { Acute infectious or } \\
\text { post-infectious } \\
\text { polyneuritis ICD-9 } \\
357.0\end{array}$ & SE, PPV \\
\hline $\begin{array}{l}\text { Calzari } \\
2006\end{array}$ & $\begin{array}{l}\text { To evaluate their accuracy for the } \\
\text { diagnosis of lymphoid malignancies }\end{array}$ & $\begin{array}{l}\text { Reggio Emilia } \\
\text { district }\end{array}$ & $1997-2001$ & $\begin{array}{l}\text { Hospital } \\
\text { discharge } \\
\text { data, death } \\
\text { certificates, } \\
\text { pathologic } \\
\text { records }\end{array}$ & $\begin{array}{l}\text { Hodgkin's and } \\
\text { non-Hodgkin } \\
\text { lymphoma, } \\
\text { multiple myeloma, } \\
\text { acute and chronic } \\
\text { lymphatic } \\
\text { leukemia, } \\
\text { Waldenstrom's } \\
\text { disease. ICD-9 } \\
\text { codes not listed }\end{array}$ & SE \\
\hline $\begin{array}{l}\text { Cattaruzzi } \\
1999\end{array}$ & $\begin{array}{l}\text { To assess the accuracy of ICD-9 } \\
\text { codes for gastrointestinal bleeding. }\end{array}$ & $\begin{array}{l}\text { Friuli-Venezia } \\
\text { Giulia region }\end{array}$ & $\begin{array}{l}\text { January } \\
1991 \text { - June } \\
1995\end{array}$ & $\begin{array}{c}\text { Medical } \\
\text { chart review }\end{array}$ & $\begin{array}{c}\text { Upper } \\
\text { Gastrointestinal } \\
\text { Bleeding: ICD-9 } \\
\text { (site- and lesion- } \\
\text { specific codes) } \\
531 \text { to } 534 \text {; (non- } \\
\text { specific codes) } \\
578.0,578.1 \text {, } \\
578.9 \text { ) }\end{array}$ & PPV \\
\hline Chiò 2002 & $\begin{array}{l}\text { To assess the validity of ALS } \\
\text { discharge diagnoses }\end{array}$ & $\begin{array}{l}\text { Piemonte and } \\
\text { Valle d'Aosta } \\
\text { regions }\end{array}$ & $1995-1996$ & $\begin{array}{l}\text { Validated } \\
\text { disease } \\
\text { register }\end{array}$ & $\begin{array}{l}\text { Amyotrophic } \\
\text { lateral sclerosis: } \\
\text { ICD-9 335.2. }\end{array}$ & SE, PPV \\
\hline Fano 2012 & $\begin{array}{l}\text { To assess the outcome "thirty days } \\
\text { mortality after admission for } \\
\text { reacutized COPD" before and after a } \\
\text { reabstract study. }\end{array}$ & $\begin{array}{l}\text { Grassi Hospital } \\
\text { (Lazio region) }\end{array}$ & $2006-2007$ & $\begin{array}{c}\text { Medical } \\
\text { chart review }\end{array}$ & $\begin{array}{c}\text { COPD (primary } \\
\text { diagnosis): ICD-9- } \\
\text { CM codes: 490, } \\
\text { 491, 492, } 494 \text { o } \\
\text { 496; Acute } \\
\text { respiratory failure } \\
\text { (secondary } \\
\text { diagnosis): ICD-9- } \\
\text { CM 518.81, } \\
\text { 518.82, 518.83, } \\
518.84 .\end{array}$ & Descriptive \\
\hline $\begin{array}{l}\text { Franchi } \\
2013\end{array}$ & $\begin{array}{l}\text { To correlate clinical data and } \\
\text { administrative data on epilepsy }\end{array}$ & $\begin{array}{l}\text { District of Lecco } \\
\quad \text { (Lombardia } \\
\text { region) }\end{array}$ & $2000-2008$ & $\begin{array}{l}\text { General } \\
\text { practitioner } \\
\text { record }\end{array}$ & $\begin{array}{c}\text { Epilepsy: ICD-9- } \\
\text { CM code: } 345 . x ; \\
\text { myoclonus: } 333.2 \text {; } \\
\text { convulsions: } \\
\text { 780.3; neonatal } \\
\text { seizures: } 779.0 ; \\
\text { spasms, other } \\
\text { abnormal } \\
\text { involuntary } \\
\text { movements: } \\
781.0 .\end{array}$ & $\begin{array}{l}\text { SE, SP, } \\
\text { PPV, NPV, } \\
\quad \text { AUC }\end{array}$ \\
\hline
\end{tabular}


(Table 1). Continued.

\begin{tabular}{|c|c|c|c|c|c|c|}
\hline Study ID & Study aim & Source & $\begin{array}{l}\text { Enrollment } \\
\text { period }\end{array}$ & $\begin{array}{l}\text { Reference } \\
\text { standard }\end{array}$ & $\begin{array}{l}\text { Type of disease: } \\
\text { ICD-9 code } \\
\text { validated }\end{array}$ & $\begin{array}{l}\text { Measure of } \\
\text { accuracy } \\
\text { used }\end{array}$ \\
\hline $\begin{array}{l}\text { Galdarossa } \\
\quad 2012\end{array}$ & $\begin{array}{l}\text { To assess the epidemiology of } \\
\text { thrombocytopenia }\end{array}$ & Padova Hospital & 2004-2008 & $\begin{array}{l}\text { Medical } \\
\text { chart } \\
\text { review }\end{array}$ & $\begin{array}{l}\text { Thrombocytopenia: } \\
\text { ICD-9-CM 287.30, } \\
31,32,33,39\end{array}$ & $\begin{array}{l}\text { SE, SP, } \\
\text { PPV, NPV }\end{array}$ \\
\hline $\begin{array}{l}\text { Leone } \\
2004\end{array}$ & $\begin{array}{l}\text { To evaluate the accuracy of stroke- } \\
\text { related ICD- } 9 \text { codes }\end{array}$ & Novara Hospital & 1998 & $\begin{array}{l}\text { Medical } \\
\text { chart } \\
\text { review }\end{array}$ & $\begin{array}{l}\text { Stroke and TIA: } \\
\text { ICD-9: } 430,431 \\
434,435 \text { and } 436\end{array}$ & SE, PPV \\
\hline $\begin{array}{l}\text { Palange } \\
2004\end{array}$ & $\begin{array}{l}\text { To estimate pleural mesothelioma } \\
\text { incidence in the Lazio region }\end{array}$ & Lazio region & $1997-2000$ & $\begin{array}{l}\text { Medical } \\
\text { chart } \\
\text { review }\end{array}$ & $\begin{array}{l}\text { Pleural } \\
\text { mesothelioma ICD- } \\
\text { 9:163.0-9 }\end{array}$ & Descriptive \\
\hline Pisa 2009 & $\begin{array}{c}\text { To evaluate the accuracy of hospital } \\
\text { discharge data as a source of ALS } \\
\text { cases. }\end{array}$ & $\begin{array}{l}\text { Friuli-Venezia } \\
\text { Giulia region }\end{array}$ & $2005-2006$ & $\begin{array}{l}\text { Medical } \\
\text { chart } \\
\text { review }\end{array}$ & $\begin{array}{l}\text { Amyotrophic } \\
\text { Lateral Sclerosis: } \\
\text { ICD9-CM } 335.20\end{array}$ & $\begin{array}{c}\text { SE, SP, PPV } \\
\text { NPV }\end{array}$ \\
\hline $\begin{array}{l}\text { Schifano } \\
2006\end{array}$ & $\begin{array}{c}\text { To identify Indicators of breast cancer } \\
\text { severity and appropriateness of } \\
\text { surgery }\end{array}$ & Lazio region & $1997-1998$ & $\begin{array}{l}\text { Medical } \\
\text { chart } \\
\text { review }\end{array}$ & $\begin{array}{l}\text { Breast cancer: } \\
\text { ICD-9-CM 174.0- } \\
\text { 174.9; } 233.0 .\end{array}$ & SE, SP, PPV \\
\hline $\begin{array}{l}\text { Spolaore } \\
2005\end{array}$ & $\begin{array}{c}\text { To assess the accuracy of hospital } \\
\text { discharge diagnoses }\end{array}$ & Veneto region & 1999 & $\begin{array}{l}\text { Medical } \\
\text { chart } \\
\text { review }\end{array}$ & $\begin{array}{l}\text { Stroke: ICD-9: } 342 \text {, } \\
430 \text { to } 434 \text {, and } \\
436 \text { to } 438\end{array}$ & PPV \\
\hline Tinelli 2002 & $\begin{array}{l}\text { To describe the frequency and type of } \\
\text { infections acquired by patients } \\
\text { hospitalized in rehabilitation units }\end{array}$ & $\begin{array}{c}131 \\
\text { rehabilitation } \\
\text { units } \\
\text { (Lombardia } \\
\text { region) }\end{array}$ & $2005-2006$ & $\begin{array}{l}\text { Medical } \\
\text { chart } \\
\text { review }\end{array}$ & $\begin{array}{l}\text { ICD-9 related to } \\
\text { infections not listed }\end{array}$ & SE, PPV \\
\hline
\end{tabular}

$\mathrm{SE}=$ Sensitivity; $\mathrm{SP}=$ Specificity; $\mathrm{PPV}=$ positive predictive value; NPV= negative predictive value; $\mathrm{AUC}=\mathrm{Area}$ under the curve; $\mathrm{ALS}=\mathrm{Amyotrophic}$ lateral sclerosis NSAID= Non-steroidal anti-inflammatory drug; $\mathrm{Cl}=$ Confidence interval; $\mathrm{TIA}=$ Transient ischemic attack; $\mathrm{COPD}=\mathrm{Chronic}$ obstructive pulmonary disease; ICD-9= International Classification of Disease.

\section{Quality of the Studies}

The quality of reporting is summarized in Table 2. Except for 2 studies that used registries [26, 29] and 1 that used general practitioner record [34], all the studies used medical chart reviews as the reference standard; two studies, in addition to the assessment of medical chart reviews, used clinical assessment [37] or disease registry [27]. Only 9 studies described the characteristics of the assessors examining the reference standard; 3 of these studies reported the blinding of the evaluator. None of these 9 studies reported whether there was more than one assessor or reported the agreement between assessors.

In terms of the estimates of accuracy, only 3 studies reported at least 4 estimates of diagnostic accuracy. The most common statistics used to estimate diagnostic accuracy were sensitivity $(n=12)$, positive predictive value (PPV) $(n=12)$, and specificity $(n=6)$. While two studies used PPV only, two studies did not report any diagnostic estimate despite the possibility to indirectly construct a cross-tabulation [24, 34]; and ten studies did not report the confidence interval for the diagnostic estimate.

\section{Productivity of Validated Administrative Databases}

The administrative database of Lombardia contained validated ICD-9 codes for four diseases of which two, Guillain-Barrè syndrome and amyotrophic lateral sclerosis, were rare diseases. Despite the number of citations related to the codes of these rare diseases, only one study that evaluated the incidence of amyotrophic lateral sclerosis in Lombardia was considered to have used the validated ICD-9 codes.

The administrative database of Piemonte included validated ICD-9 codes for stroke, amyotrophic lateral sclerosis and tumors of the breast, the colon and the lungs. Overall, there were 67 citations identified, of which 5 had indicated using the validated codes for research. 
Table 2: Quality of Reporting of Included Studies Based on a Modified STARD Guidelines

\begin{tabular}{|c|c|c|c|c|}
\hline TITLE, KEYWORDS, ABSTRACT & Yes & No & Unclear & $\begin{array}{l}\text { Not } \\
\text { applicable }\end{array}$ \\
\hline Identify article as study of assessing diagnostic accuracy & $12(75 \%)$ & $4(25 \%)$ & $0(0 \%)$ & $0(0 \%)$ \\
\hline Identify article as study of administrative data & $11(69 \%)$ & $4(25 \%)$ & $1(6 \%)$ & $0(0 \%)$ \\
\hline \multicolumn{5}{|l|}{ INTRODUCTION } \\
\hline State disease identification \& validation one of goals of study & $14(88 \%)$ & $2(13 \%)$ & $0(0 \%)$ & $0(0 \%)$ \\
\hline \multicolumn{5}{|l|}{ METHODS } \\
\hline \multicolumn{5}{|l|}{ Participants in validation cohort: } \\
\hline Describe validation cohort (Cohort of patients to which reference standard was applied) & $16(100 \%)$ & $0(0 \%)$ & $0(0 \%)$ & $0(0 \%)$ \\
\hline Age & $7(44 \%)$ & $7(44 \%)$ & $2(13 \%)$ & $0(0 \%)$ \\
\hline - Disease & $13(81 \%)$ & $1(6 \%)$ & $2(13 \%)$ & $0(0 \%)$ \\
\hline - Severity & $2(13 \%)$ & $9(56 \%)$ & $3(19 \%)$ & $2(13 \%)$ \\
\hline · Location/Jurisdiction & $16(100 \%)$ & $0(0 \%)$ & $0(0 \%)$ & $0(0 \%)$ \\
\hline \multicolumn{5}{|l|}{ Describe recruitment procedure of validation cohort: } \\
\hline - Inclusion criteria & $15(94 \%)$ & $0(0 \%)$ & $1(6 \%)$ & $0(0 \%)$ \\
\hline - Exclusion criteria & $3(19 \%)$ & $4(25 \%)$ & $9(56 \%)$ & $0(0 \%)$ \\
\hline Describe patient sampling (random, consecutive, all, etc.) & $16(100 \%)$ & $0(0 \%)$ & $0(0 \%)$ & $0(0 \%)$ \\
\hline \multicolumn{5}{|l|}{ Describe data collection } \\
\hline - Who identified patients and did selection adhere to patient recruitment criteria & $7(44 \%)$ & $0(0 \%)$ & $9(56 \%)$ & $0(0 \%)$ \\
\hline - Who collected data & $4(25 \%)$ & $0(0 \%)$ & $12(75 \%)$ & $0(0 \%)$ \\
\hline A priori data collection form & $3(19 \%)$ & $2(13 \%)$ & $11(69 \%)$ & $0(0 \%)$ \\
\hline Disease classification & $9(56 \%)$ & $0(0 \%)$ & $7(44 \%)$ & $0(0 \%)$ \\
\hline - Split sample (i.e. re-validation using a separate cohort) & $2(13 \%)$ & $5(31 \%)$ & $9(56 \%)$ & $0(0 \%)$ \\
\hline \multicolumn{5}{|l|}{ Test Methods: } \\
\hline Describe number, training and expertise of persons reading reference standard & $9(56 \%)$ & $1(6 \%)$ & $6(38 \%)$ & $0(0 \%)$ \\
\hline $\begin{array}{l}\text { If >1 person reading reference standard, quote measure of consistency (e.g. } \\
\text { kappa) }\end{array}$ & $0(0 \%)$ & $8(50 \%)$ & $5(31 \%)$ & $3(19 \%)$ \\
\hline $\begin{array}{l}\text { Blinding of interpreters of reference standard to results of classification by } \\
\text { administrative data (e.g. Chart abstractor blinded to how that chart was coded) }\end{array}$ & $3(19 \%)$ & $1(6 \%)$ & $12(75 \%)$ & $0(0 \%)$ \\
\hline \multicolumn{5}{|l|}{ Statistical Methods: } \\
\hline Describe methods of calculating/comparing diagnostic accuracy & $10(63 \%)$ & $4(25 \%)$ & $2(13 \%)$ & $0(0 \%)$ \\
\hline \multicolumn{5}{|l|}{ RESULTS: } \\
\hline \multicolumn{5}{|l|}{ Participants: } \\
\hline Report when study done, start/end dates of enrollment & $14(88 \%)$ & $0(0 \%)$ & $2(13 \%)$ & $0(0 \%)$ \\
\hline Describe number of people who satisfied inclusion/exclusion criteria & $15(94 \%)$ & $0(0 \%)$ & $0(0 \%)$ & $1(6 \%)$ \\
\hline Study flow diagram & $5(31 \%)$ & $11(69 \%)$ & $0(0 \%)$ & $0(0 \%)$ \\
\hline \multicolumn{5}{|l|}{ Test results: } \\
\hline Report distribution of disease severity & $2(13 \%)$ & $5(31 \%)$ & $5(31 \%)$ & $4(25 \%)$ \\
\hline Report cross-tabulation of index tests by results of reference standard & $10(63 \%)$ & $6(38 \%)$ & $0(0 \%)$ & $0(0 \%)$ \\
\hline \multicolumn{5}{|l|}{ Estimates: } \\
\hline Report at least 4 estimates of diagnostic accuracy & $3(19 \%)$ & $13(81 \%)$ & $0(0 \%)$ & $0(0 \%)$ \\
\hline
\end{tabular}


(Table 2). Continued.

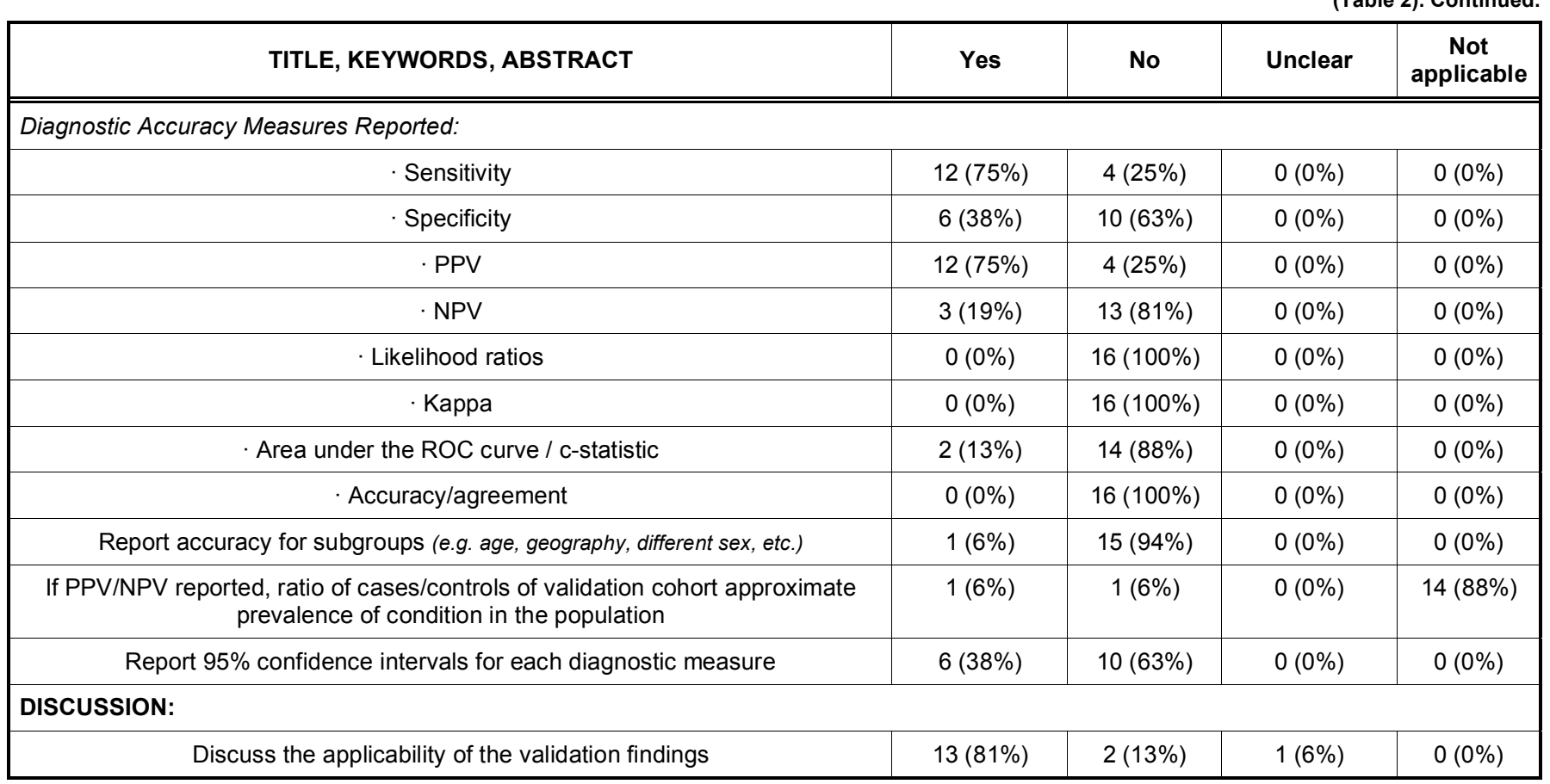

PPV, positive predictive value; NPV, negative predictive value; ROC, receiver operating characteristic; $\mathrm{Cl}$, confidence interval.

The administrative database of Lazio comprised validated ICD-9 codes for COPD, breast cancer, mesothelioma and received 13 citations using the validated codes.

The administrative database of Friuli Venezia-Giulia included validated ICD-9 codes for gastrointestinal bleeding and amyotrophic lateral sclerosis. The study that documented the validation of the rare disease, amyotrophic lateral sclerosis, was published in 2009 and did not receive any citation [30]. Conversely, the study that validated the codes for gastrointestinal bleeding received at least 75 citations of which 2 employed the validated ICD-9 codes $[38,39]$.

The only publication that had validated stroke related diseases, from the administrative databases of Veneto, received 35 citations none of which was pertinent to the validated database. The remaining databases did not receive any citations. Table 3 shows the ICD-9 codes that were validated, with the related diagnostic accuracy estimates, the number of citations from Scopus and Google Scholar and the subsequent research based on the validated disease codes.

\section{DISCUSSION}

As the use of administrative healthcare databases grows, validation is increasingly recognized as an important component of research [2, 15, 40-42]. In this comprehensive systematic review, we identified 16 studies that performed the process of validation of diagnostic codes for healthcare administrative databases in Italy. Despite their widespread presence, only 5 regional administrative databases were effectively validated and only for ICD-9 codes of a limited number of diseases. In addition, we were able to assess the practical use of the databases for research by using the Scopus and Google Scholar databases to identify published articles that had cited the validated databases.

In general, some researchers were more oriented towards validation of rare diseases in administrative databases [27, 29, 30, 33]. For example, the validation of the codes for amyotrophic lateral sclerosis was performed in almost all the northern regions of Italy including Lombardia, Piemonte, Valle d'Aosta and Friuli-Venezia Giulia. The validation process produced some research in epidemiology and organizational assessments [43-45]. Baldi et al. [26] validated cancer related ICD-9 codes, using Piemonte's regional database, and performed subsequent studies that evaluated the determinants of patterns of healthcare and survival in lung and breast cancer [46-48]. After validating the codes for breast cancer severity, Rossi et al. used the Lazio regional administrative database to assess the efficacy of breast cancer screening programs $[49,50]$.

For frequent diseases such as stroke, researchers were able to validate the codes in three databases $(2$ of 
Table 3: Administrative Databases with Results of Validated ICD-9 Codes and Relevant Citations

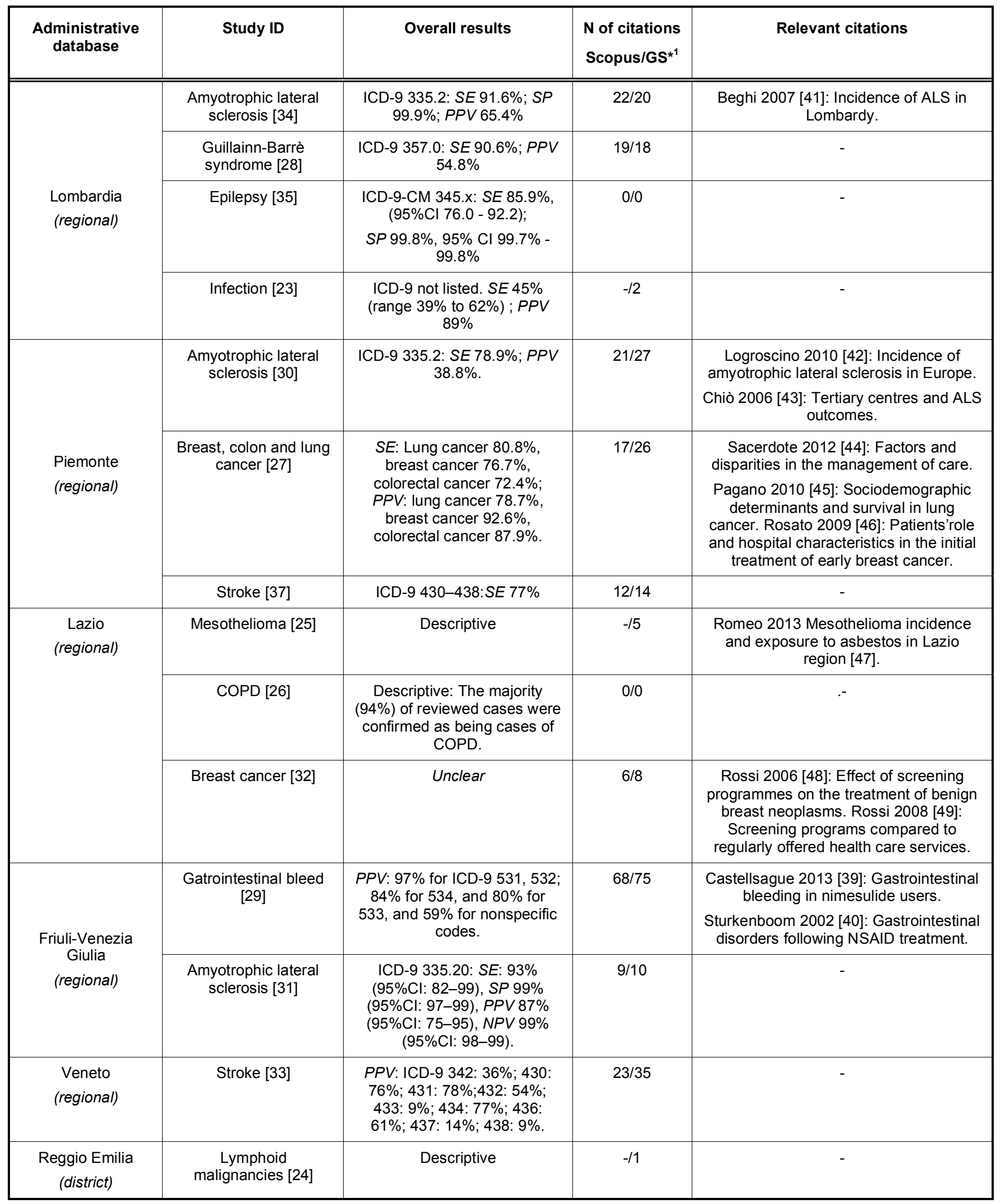


(Table 3). Continued.

\begin{tabular}{|c|c|c|c|c|}
\hline $\begin{array}{l}\text { Administrative } \\
\text { database }\end{array}$ & Study ID & Overall results & $\begin{array}{l}\mathbf{N} \text { of citations } \\
\text { Scopus/GS }{ }^{* 1}\end{array}$ & Relevant citations \\
\hline $\begin{array}{l}\text { Padova } \\
\text { (hospital) }\end{array}$ & Thrombocitopenia [36] & $\begin{array}{c}\text { ICD-9-CM 287.31: SE:80\% } \\
(95 \% \mathrm{Cl} 0.51-0.94) ; \mathrm{SP}: 88 \% \\
(95 \% \mathrm{Cl} 0.67-0.96) \text { PPV:80\% } \\
(95 \% \mathrm{Cl} 0.56-0.97) ; \\
\text { NPV:88.4\%(95\%Cl } 0.68- \\
0.96 \%)\end{array}$ & $1 / 2$ & - \\
\hline $\begin{array}{l}\text { Lugo di Romagna } \\
\text { (hospital) }\end{array}$ & Stroke [38] & $\begin{array}{c}\text { ICD-9 434: SE 82\%, PPV } \\
\text { 71\%; ICD-9 436: SE } 76 \% \\
\text { PPV 76\% }\end{array}$ & $15-22$ & - \\
\hline
\end{tabular}

${ }^{1} \mathrm{GS}=$ Google Scholar; $\mathrm{SE}=$ Sensitivity; $\mathrm{SP}=$ Specificity; $\mathrm{PPV}=$ positive predictive value; $\mathrm{NPV}=$ negative predictive value; $\mathrm{AUC}=\mathrm{Area}$ under the curve; $\mathrm{ALS}=$ Amyotrophic lateral sclerosis; NSAID= Non-steroidal anti-inflammatory drug; $\mathrm{Cl}=$ Confidence interval; $\mathrm{TIA}=$ Transient ischemic attack; COPD=Chronic obstructive pulmonary disease; ICD-9= International Classification of Disease.

which were large regional databases, Table 3), but they did not produce further research. The database from Friuli-Venezia Giulia, containing the validated ICD-9 codes for gastrointestinal bleeding, was used to evaluate the association between nimesulide and other non-steroidal anti-inflammatory drugs and gastrointestinal bleeding [28, 38, 39].

\section{STRENGTH AND LIMITATIONS}

We used the search strategy developed by Benchimol et al. [15], because, unlike other search strategies of administrative data [51], it was more oriented to identifying validation studies with very high sensitivity and low specificity, generating a large number of abstracts to evaluate. Despite this aspect, Benchimol's search strategy may not have captured all the relevant records, either because some abstracts may have not used relevant keywords or because Italian was used. To overcome this limitation, we searched the Internet, the Italian Regional and Local Health Unit websites, relevant regional health reports and relevant Italian journals, which led to identifying 6 articles. Another limitation might have been the use of Scopus or Google Scholar to search for study citations as a secondary indicator of research productivity of validated administrative databases. First, this approach is not a reliable tool, especially when the validation study was recently published, as it requires considerable time to publish the results of research using databases. Second, the accessibility of these databases can differ, which may have influenced the indicators of research productivity of the databases, even for the 8 codes validated at least 10 years ago. However, further investigation is necessary to explore the issue of accessibility of databases.

\section{SIGNIFICANCE AND CONCLUSION}

Healthcare databases in Italy experienced a rapid growth as a consequence of the introduction of the Diagnosis-Related Group (DRG) system in 1995. This system was initially used for reimbursement purposes, and subsequently, for the measurement of healthcare performance [10]. Discharge abstract data included the ICD-9 codes (which was replaced by the ICD-9-CM codes) and a number of procedures. Individual health and drug use data are collected using a unique lifetime fiscal code, similar to social security numbers in the US, which is provided to all residents. The use of a unique code allows linking diverse data, including pharmaceutical and immunization records and outpatient clinical diagnoses, and permits collecting information even when the patient receives health assistance from different regions.

Debates on the use of administrative databases routinely occur [12] and algorithms have been proposed to assess the disease status of large populations in Italy [52, 53]. In general, Italian administrative databases have the potential to address important questions in post-marketing surveillance [8, 54], epidemiology [12], quality performance and health services research [55]. In its annual review of drug utilization, the Italian Medicines Agency (AIFA), reported a list of 103 peer-reviewed publications of drug utilization studies performed in Italy [56]. Although most of these studies were focused on drug utilization and compliance, pharmacoeconomics and healthcare performance, this indicated that databases were widely used.

In conclusion, administrative databases in Italy are a valuable source of patient healthcare information that can be employed for a variety of studies with a 
potentially high impact on public health policy and health care spending, but these databases require an extensive process of validation of multiple diagnostic codes.

\section{ABBREVIATIONS}

$\begin{aligned} \text { ICD }= & \text { International Classification of Diseases } \\ \text { STARD = } & \begin{array}{l}\text { Standards for Reporting of Diagnostic } \\ \text { accuracy }\end{array} \\ \text { COPD = } & \begin{array}{l}\text { chronic obstructive pulmonary disease } \\ \text { cases }\end{array} \\ \text { AIFA = } & \begin{array}{l}\text { Agenzia Italiana del Farmaco (Italian } \\ \text { Medicines Agency) }\end{array} \\ \text { DRG = } & \text { Diagnosis-Related Group }\end{aligned}$

\section{COMPETING INTERESTS}

The authors declare that they have no competing interests

\section{AUTHORS' CONTRIBUTIONS}

$I A$ and $A M$ conceived the paper; IA, AM, LF, RC, $P G, P C$ drafted the manuscript; IA, MO, PG, FC, MLL, $R C$, $L F$ participated in the design of the study; MLL, RD FC, MO acquired the data; IA, PE, RDF, GG, AM, MM analysed and interpretation the data; IA, AM, MO,PG, FC, PE, MM, MLL, GG revised critically the manuscript for important intellectual content. All authors read and approved the final manuscript.

\section{ACKNOWLEDGEMENTS}

We thank Joseph M Rimland for English editing and Nadia Gaggioli for helping in retrieving full-text articles.

\section{SUPPLEMENTAL MATERIAL}

The supplemental material can be downloaded from the journal website along with the article.

\section{REFERENCES}

[1] Schneeweiss S, Avorn J. A review of uses of health care utilization databases for epidemiologic research on therapeutics. J Clin Epidemiol 2005; 58: 323-37. http://dx.doi.org/10.1016/j.jclinepi.2004.10.012

[2] Prins H, Hasman A. Appropriateness of ICD-coded diagnostic inpatient hospital discharge data for medical practice assessment. A systematic review. Methods of information in medicine 2013; 52: 3-17. http://dx.doi.org/10.3414/ME12-01-0022
[3]

World Health Organization. International statistical classification of diseases and health related problems, 10th revision. Geneva: WHO 1992.

[4] lezzoni LI. Assessing quality using administrative data Annals of internal medicine 1997; 127: 666-74. http://dx.doi.org/10.7326/0003-4819-127-8 Part 2199710151-00048

[5] West SL, Strom BL, Poole C. Validity of Pharmacoepidemiologic Drug and Diagnosis Data: John Wiley \& Sons, Ltd; 2007. 709-65 p.

[6] Lalmohamed A, Vestergaard P, Cooper C, de Boer A, et al. Timing of stroke in patients undergoing total hip replacement and matched controls: a nationwide cohort study. Stroke; a journal of cerebral circulation 2012; 43: 3225-9. http://dx.doi.org/10.1161/STROKEAHA.112.668509

Hottes TS, Skowronski DM, Hiebert B, Janjua NZ, et al. Influenza vaccine effectiveness in the elderly based on administrative databases: change in immunization habit as a marker for bias. PLoS One 2011; 6: e22618.

[8] Traversa G, Bianchi C, Da Cas R, Abraha I, Menniti-Ippolito F, Venegoni M. Cohort study of hepatotoxicity associated with nimesulide and other non-steroidal anti-inflammatory drugs. BMJ 2003; 327: 18-22. http://dx.doi.org/10.1136/bmj.327.7405.18

[9] Prieto-Alhambra D, Javaid MK, Judge A, Maskell J, et al. Hormone replacement therapy and mid-term implant survival following knee or hip arthroplasty for osteoarthritis: a population-based cohort study. Annals of the rheumatic diseases 2014

[10] Fattore G, Torbica A. Inpatient reimbursement system in Italy: how do tariffs relate to costs? Health care management science 2006; 9: 251-8. http://dx.doi.org/10.1007/s10729-006-9092-2

[11] Abraha I, Montedori A, Stracci F, Rossi M, Romagnoli C. Statin compliance in the Umbrian population. European journal of clinical pharmacology 2003; 59: 659-61. http://dx.doi.org/10.1007/s00228-003-0675-2

[12] Gini R, Francesconi P, Mazzaglia G, Cricelli I, et al. Chronic disease prevalence from Italian administrative databases in the VALORE project: a validation through comparison of population estimates with general practice databases and national survey. BMC Public Health 2013; 13: 15. http://dx.doi.org/10.1186/1471-2458-13-15

[13] Baviera M, Santalucia P, Cortesi L, Marzona I, et al. Sex differences in cardiovascular outcomes, pharmacological treatments and indicators of care in patients with newly diagnosed diabetes: Analyses on administrative database. European journal of internal medicine 2014 http://dx.doi.org/10.1016/j.ejim.2014.01.022

[14] Bottacchi E, Corso G, Tosi P, Morosini MV, et al. The cost of first-ever stroke in Valle d'Aosta, Italy: linking clinical registries and administrative data. BMC health services research 2012; 12: 372.

http://dx.doi.org/10.1186/1472-6963-12-372

[15] Benchimol El, Manuel DG, To T, Griffiths AM, Rabeneck L, Guttmann A. Development and use of reporting guidelines for assessing the quality of validation studies of health administrative data. J Clin Epidemiol 2011; 64: 821-9. http://dx.doi.org/10.1016/j.jclinepi.2010.10.006

[16] Bossuyt PM, Reitsma JB, Bruns DE, Gatsonis CA, et al. Towards complete and accurate reporting of studies of diagnostic accuracy: The STARD Initiative. Annals of internal medicine 2003; 138: 40-4. http://dx.doi.org/10.7326/0003-4819-138-1-200301070$\underline{00010}$

[17] Carrara G, Scire CA, Cimmino MA, Zambon A, et al. Derivation and validation of a diagnostic algorithm to identify patients with rheumatoid arthritis in administrative health database. Annals of the rheumatic diseases 2013; 72. 
[18] Faustini A, Canova C, Cascini S, Baldo V, et al. The reliability of hospital and pharmaceutical data to assess prevalent cases of chronic obstructive pulmonary disease. Copd. 9: 184-96.

[19] Valkhoff VE, Coloma PM, Lapi F, Gini R, et al. Positive predictive value for upper gastrointestinal bleeding in four health care databases using different coding systems in the EU-ADR project. Pharmacoepidemiology and Drug Safety. 21: 393.

[20] Coloma PM, Valkhoff VE, Mazzaglia G, Nielsson MS, et al. Accuracy of coding-based algorithms in identification of acute myocardial infarction from multi-country electronic healthcare records (EHR) databases. Pharmacoepidemiology and Drug Safety 2012; 21: 395-6.

[21] Moro ML, Morsillo F. Can hospital discharge diagnoses be used for surveillance of surgical-site infections? J Hosp Infect 2004; 56: 239-41. http://dx.doi.org/10.1016/j.jhin.2003.12.022

[22] Tinelli M, Mannino S, Lucchi S, Piatti A, et al. Healthcareacquired infections in rehabilitation units of the Lombardy Region, Italy. Infection 2002; 39: 353-8.

http://dx.doi.org/10.1007/s15010-011-0152-2

[23] Calzari MG, Vinceti M, Avanzini P, Rodolfi R, et al. [Sensitivity and accuracy of health databases in determining incidence of lymphoid malignancies in an Italian population]. Annali di Igiene 2006; 18: 127-36.

[24] Palange S, Ascoli V, Carnovale-Scalzo C, Forastiere F, et al. Stime di incidenza del mesotelioma pleurico nel Lazio. Med Lav 2004; 95: 45-54.

[25] Fano V, D'Ovidio M, del Zio K, Renzi D, et al. [The role of the quality of hospital discharge records on the comparative evaluation of outcomes: the example of chronic obstructive pulmonary disease (COPD)]. Epidemiol Prev 2011; 36: 1729.

[26] Baldi I, Vicari P, Di Cuonzo D, Zanetti R, et al. A high positive predictive value algorithm using hospital administrative data identified incident cancer cases. Journal of Clinical Epidemiology 2008; 61: 373-9.

http://dx.doi.org/10.1016/j.jclinepi.2007.05.017

[27] Bogliun G, Beghi E. Validity of hospital discharge diagnoses for public health surveillance of the Guillain-Barré syndrome. Neurol Sci 2002; 23: 113-7. http://dx.doi.org/10.1007/s100720200036

[28] Cattaruzzi C, Troncon MG, Agostinis L, Garcia Rodriguez LA. Positive predictive value of ICD-9th codes for upper gastrointestinal bleeding and perforation in the Sistema Informativo Sanitario Regionale database. Journal of Clinical Epidemiology 1999; 52: 499-502. http://dx.doi.org/10.1016/S0895-4356(99)00004-9

[29] Chio A, Ciccone G, Calvo A, Vercellino M, et al. Validity of hospital morbidity records for amyotrophic lateral sclerosis. A population-based study. J Clin Epidemiol 2002; 55: 723-7. http://dx.doi.org/10.1016/S0895-4356(02)00409-2

[30] Pisa FE, Verriello L, Deroma L, Drigo D, et al. The accuracy of discharge diagnosis coding for Amyotrophic Lateral Sclerosis in a large teaching hospital. European journal of epidemiology 2009; 24: 635-40.

http://dx.doi.org/10.1007/s10654-009-9376-1

[31] Schifano $P$, Papini $P$, Agabiti $N$, Scarinci $M$, Borgia $P$, Perucci CA. Indicators of breast cancer severity and appropriateness of surgery based on hospital administrative data in the Lazio Region, Italy. BMC Public Health 2006; 6: 25.

http://dx.doi.org/10.1186/1471-2458-6-25

[32] Spolaore P, Brocco S, Fedeli U, Visentin C, et al. Measuring accuracy of discharge diagnoses for a region-wide surveillance of hospitalized strokes. Stroke; a journal of cerebral circulation 2005; 36: 1031-4.

http://dx.doi.org/10.1161/01.STR.0000160755.94884.4a
[33] Beghi E, Logroscino G, Micheli A, Millul A, et al. Validity of hospital discharge diagnoses for the assessment of the prevalence and incidence of amyotrophic lateral sclerosis. Amyotrophic Lateral Sclerosis and Other Motor Neuron Disorders 2001; 2: 99-104. http://dx.doi.org/10.1080/146608201316949541

[34] Franchi C, Giussani G, Messina P, Montesano M, et al. Validation of healthcare administrative data for the diagnosis of epilepsy. Journal of epidemiology and community health 2013; 67: 1019-24. http://dx.doi.org/10.1136/jech-2013-202528

[35] Galdarossa M, Vianello F, Tezza F, Allemand E, et al. Epidemiology of primary and secondary thrombocytopenia: first analysis of an administrative database in a major Italian institution. Blood Coagul Fibrinolysis. 23: 271-7. http://dx.doi.org/10.1097/MBC.0b013e328351882d

[36] Leone MA, Capponi A, Varrasi C, Tarletti R, Monaco F. Accuracy of the ICD-9 codes for identifying TIA and stroke in an Italian automated database. Neurol Sci 2004; 25: 281-8. http://dx.doi.org/10.1007/s10072-004-0355-8

[37] Rinaldi R, Vignatelli L, Galeotti M, Azzimondi G, De Carolis $P$. Accuracy of ICD-9 codes in identifying ischemic stroke in the General Hospital of Lugo di Romagna (Italy). Neurol Sci 2003; 24: 65-9.

[38] Castellsague J, Pisa F, Rosolen V, Drigo D, et al. Risk of upper gastrointestinal complications in a cohort of users of nimesulide and other nonsteroidal anti-inflammatory drugs in Friuli Venezia Giulia, Italy. Pharmacoepidemiol Drug Saf 2013; 22: 365-75. http://dx.doi.org/10.1002/pds.3385

[39] Sturkenboom MC, Romano F, Simon G, Correa-Leite ML, et al. The iatrogenic costs of NSAID therapy: a population study. Arthritis and rheumatism 2002; 47: 132-40. http://dx.doi.org/10.1002/art.10268

[40] Li X, Hilsden R, Hossain S, Fleming J, Winget M. Validation of administrative data sources for endoscopy utilization in colorectal cancer diagnosis. BMC Health Serv Res 2012; 12: 358.

http://dx.doi.org/10.1186/1472-6963-12-358

[41] Myers R, Leung Y, Shaheen A, Li B. Validation of ICD-9CM/ICD-10 coding algorithms for the identification of patients with acetaminophen overdose and hepatotoxicity using administrative data. BMC Health Serv Res 2007; 7: 159. http://dx.doi.org/10.1186/1472-6963-7-159

[42] Harris S, Glazier R, Tompkins J, Wilton A, et al. Investigating concordance in diabetes diagnosis between primary care charts (electronic medical records) and health administrative data: a retrospective cohort study. BMC Health Serv Res 2010; 10: 347. http://dx.doi.org/10.1186/1472-6963-10-347

[43] Beghi E, Millul A, Micheli A, Vitelli E, Logroscino G, Group S. Incidence of ALS in Lombardy, Italy. Neurology 2007; 68: 141-5.

http://dx.doi.org/10.1212/01.wnl.0000250339.14392.bb

[44] Logroscino G, Traynor BJ, Hardiman O, Chio A, et al Incidence of amyotrophic lateral sclerosis in Europe. Journal of neurology, neurosurgery, and psychiatry 2010; 81: 385-90. http://dx.doi.org/10.1136/jnnp.2009.183525

[45] Chio A, Bottacchi E, Buffa C, Mutani R, Mora G, Parals. Positive effects of tertiary centres for amyotrophic lateral sclerosis on outcome and use of hospital facilities. Journal of neurology, neurosurgery, and psychiatry 2006; 77: 948-50. http://dx.doi.org/10.1136/jnnp.2005.083402

[46] Sacerdote C, Baldi I, Bertetto O, Dicuonzo D, et al. Hospital factors and patient characteristics in the treatment of colorectal cancer: a population based study. BMC Public Health 2012; 12: 775.

http://dx.doi.org/10.1186/1471-2458-12-775 
[47] Pagano E, Filippini C, Di Cuonzo D, Ruffini E, et al. Factors affecting pattern of care and survival in a population-based cohort of non-small-cell lung cancer incident cases. Cancer epidemiology 2010; 34: 483-9.

http://dx.doi.org/10.1016/j.canep.2010.04.002

[48] Rosato R, Sacerdote C, Pagano E, Di Cuonzo D, et al. Appropriateness of early breast cancer management in relation to patient and hospital characteristics: a population based study in Northern Italy. Breast cancer research and treatment 2009; 117: 349-56. http://dx.doi.org/10.1007/s10549-008-0252-6

[49] Giorgi Rossi P, Chini F, Barca A, Baiocchi D, et al. Efficacy of disease management profiles. The mammographic screening program of Lazio. Tumori 2008; 94: 297-303. http://dx.doi.org/10.1258/096914106778440662

[50] Giorgi Rossi P, Federici A, Farchi S, Chini F, et al. The effect of screening programmes on the treatment of benign breast neoplasms: observations from current practice in Italy. Journal of medical screening 2006; 13: 123-8.

[51] Van Walraven C, Bennett C, Forster AJ. Derivation and validation of a MEDLINE search strategy for research studies that use administrative data. Health services research 2010; 45: $1836-45$.

http://dx.doi.org/10.1111/j.1475-6773.2010.01159.x
[52] Tessari R, Migliore E, Balzi D, Barchielli A, et al. [Asthma prevalence estimated using a standard algorithm based on electronic health data in various areas of Italy]. Epidemiol Prev 2008; 32: 56-65.

[53] Migliore E, Bugiani M, Piccioni P, Galassi C, et al. [Obstructive lung disease prevalence estimated using a standard algorithm based on electronic health data in various areas of Italy]. Epidemiol Prev 2008; 32: 66-77.

[54] Trifiro G, Patadia V, Schuemie MJ, Coloma PM, et al. EUADR healthcare database network vs. spontaneous reporting system database: preliminary comparison of signal detection. Studies in health technology and informatics 2011; 166: 2530.

[55] Colais P, Pinnarelli L, Fusco D, Davoli M, Braga M, Perucci $\mathrm{CA}$. The impact of a pay-for-performance system on timing to hip fracture surgery: experience from the Lazio Region (Italy). BMC health services research 2013; 13: 393. http://dx.doi.org/10.1186/1472-6963-13-393

[56] OsMed Gdl. L'uso dei farmaci in Italia - Rapporto nazionale anno 2010. II Pensiero Scientifico Editore 2011.

http://dx.doi.org/10.6000/1929-6029.2014.03.03.10

(C) 2014 Abraha et al.; Licensee Lifescience Global.

This is an open access article licensed under the terms of the Creative Commons Attribution Non-Commercial License (http://creativecommons.org/licenses/by-nc/3.0/) which permits unrestricted, non-commercial use, distribution and reproduction in any medium, provided the work is properly cited. 